\title{
A Phonemic and Acoustic Analysis of Hindko Fricatives
}

\author{
Haroon Ur RASHID
}

University of Azad Jammun \& Kashmir

kharoon914@gmail.com

\author{
Abdul Qadir KHAN \\ University of Azad Jammun \& Kashmir \\ draqkhan73@yahoo.com
}

\begin{abstract}
The Hindko language is mainly spoken in the province of Khyber Pukhtunkhaw, Pakistan. It relates to the Indo-Aryan family of languages. This paper focusses on the phonemic and acoustic analysis of Hindko fricatives. The phonemic analysis identifies that Hindko has eight fricatives. The acoustic analysis aims to explore temporal and spectral characteristics of these fricatives. The acoustic analysis discloses that Hindko fricatives are distinguishable on the basis of the temporal properties such as friction duration and spectral cues like turbulence noise.
\end{abstract}

Keywords: Hindko; phonemic; acoustic; temporal properties; spectral cues; friction

\section{Povzetek}

Jezik Hindko priprada indo-iranski jezikovni družini in ga govorijo predvsem v pakistanski provinci Khyber Pukhtunkhaw. Ta raziskava se osredotoča na fonemsko in akustično analizo pripornikov Hindka. S fonemskega vidika ima Hindko osem pripornikov, ki so nadalje analizirani z vidika časovnih in spektralnih značilnosti. Akustične analize kažejo, da je mogoče Hindko pripornike razločiti tako glede na njihove časovne značilnosti, kot je na primer trajanje frikcije, ali pa na spektralne značilnosti, kot je na primer turbulentni hrup.

Ključne besede: Hindko; fonemsko; akustično; časovne lastnosti; spektralni pokazatelji; frikcija (trenje)

Acta Linguistica Asiatica, 4(3), 2014.

ISSN: 2232-3317, http://revije.ff.uni-lj.si/ala/

DOI: $10.4312 /$ ala.4.3.71-81 


\section{Introduction}

Hindko belongs to the Indo-Aryan family of languages that has several dialects on a regional basis (Lothers \& Lothers, 2010). Hazara dialect is one of its main dialects that is spoken in Hazara division; Khyber Pukhtunkhaw province of Pakistan. The majority of Hindko speakers live in this area (Haroon \& Sohail, 2011).

This paper presents a phonemic and acoustic analysis of Hindko fricatives. The next section offers a phonemic analysis of Hindko fricatives aiming to identify the fricatives that includes minimal pairs, voicing contrast and distribution of phonemes in words at initial, medial and end positions. The third main section describes the acoustic cues for fricatives. It reports the relevant literature on acoustic cues with a purpose to provide a foundation for the study and further states the methodology. In addition, this section also divulges the results of the study and states the intrinsic and extrinsic acoustic cues for Hindko fricatives. The last section concludes this study.

\section{Phonemic Analysis}

The fricatives are characterized by the movement of an active articulator to passive articulator without resulting in contact, but not in the center of the vocal tract, and the air is forced to pass through a narrow passage between articulators yielding friction. The phonemic analysis is presented on the basis of the minimal pairs, voicing distribution contrasts and word level distribution at initial, medial and end positions. This section also offers the outcome of the analysis.

\subsection{Minimal Pairs}

Table 1: Minimal pairs of Hindko fricatives.

\begin{tabular}{|l|l|l|l|l||}
\hline $\mathbf{f}$ & farək & difference & varək & page \\
\hline V & vakət & time & fakət & only \\
\hline S & soval & question & zoval & dusk \\
\hline Z & zədd & reach & sədd & call \\
\hline J & fəll & freeze & səll & make hole \\
\hline X & xəmm & curve & rəmm & sorrow \\
\hline r & ralaf & cover & xalaf & against \\
\hline h & halət & condition & ralət & wrong \\
\hline
\end{tabular}




\subsection{Voicing Contrast}

The following table presents voicing contrast between fricatives.

Table 2: Voicing contrast of fricatives.

\begin{tabular}{lllllll}
\hline $\mathrm{f}$ & vs & v & fott & quick & vatt & anger \\
s & vs & z & sara & whole & zara & tiny \\
$\int$ & - & - & fal & big scarf- & & \\
X & vs & r & xar & enmity & rar & cave \\
- & - & h & - & - & fal & condition \\
\hline
\end{tabular}

Table 2 shows that the voicing contrast is not found for $/ \mathrm{J} /$ and $/ \mathrm{h} /$ as these do not have their respective counter parts.

\subsection{Word level distribution}

Word level distribution of the Hindko fricatives is given below:

Table 3: Word level distribution of fricatives.

\begin{tabular}{|c|c|c|c|c|c|c|}
\hline & Initial & & Medial & & Final & \\
\hline $\mathrm{f}$ & fədzri & dawn & xəfkan & unrest & lef & quilt \\
\hline $\mathrm{v}$ & vela & free & sava & green & sev & apple \\
\hline s & & breath & pasa & side & lus & not well lit \\
\hline $\mathrm{z}$ & zImmi & land & mizman & guest & dərərəz & small gap \\
\hline $\int$ & fola & bridegroom & pe $\int i$ & a prayer & $\overrightarrow{\mathrm{r}} \partial \iint$ & crowded time \\
\hline $\mathrm{x}$ & $x \partial t t$ & trimming & moxərr & an animal & tobax & plate disease \\
\hline$\gamma$ & rənd̄lã & a vegetable & dirər & a prayer & or & a support time \\
\hline h & həkk & make move & defiar & a day & - & \\
\hline
\end{tabular}

Table 3 demonstrates that all the fricatives exist word initially, medially and finally except /h/ as it does not occur at word final position.

This phonemic analysis illustrates that Hindko has eight fricatives that are articulated from five different places namely labio-dental/f, v/, alveolar /s, z/, palatal /f/, velar $/ \mathrm{x}, \gamma /$ and glottal $/ \mathrm{h} /$. The voicing contrast is found at three places of articulation that are labio-dental /f, v/, alveolar/s, z/ and velar /x, $\gamma /$ while palatal /g/ and glottal /h/ are without this contrast. This means that Hindko has four voiceless /f, s, x, J/ and four 
voiced $/ \mathrm{v}, \mathrm{z}, \gamma, \mathrm{h} /$ fricative phonemes. Their occurrence in words is found at all positions except glottal /h/ which is restricted to only word initial and medial positions.

\section{Acoustic Analysis}

Phonetically, groups of consonants differ from each other in a variety of acoustic parameters intrinsically as well as extrinsically. Kent and Read (1996) assert that consonant groups differ considerably in their acoustic cues; due to this are difficult to describe with a single set of acoustic properties. Some consonants are articulated with a complete air blockage while other are produced with a partial blockage. Some differ in release. Such differences constitute different groups of consonants, i-e. stops, fricatives, affricates, etc. All these have different distinguishing acoustic properties. Following subsection first reports acoustic studies on fricative then states the methodology; and then discusses the acoustic properties of Hindko fricatives.

\subsection{Acoustic Studies on Fricative}

Davenport and Hannahs (2005) claim that fricatives are accompanied by a periodic vibration in the higher frequencies and main resonant frequencies. It rises as the size of the oral cavity decrease. Ladefoged (2001) found that fricatives exhibit random noise pattern in higher frequency range but conditioned to the place of articulation. Pickett (1999) believes that the overall shape of the fricatives is known by the shape and size of the cavity in front of the constriction. Kent and Read (1996) link fricatives identification with the formation of narrow constriction in the oral tract, the development of turbulent air passage and the generation of turbulence noise. There is a fair amount of studies on English fricatives (such as Hughes \& Halle, 1956; Tomiak 1990; Jongman et al 2000; etc.) whereas only a limited number of studies on fricatives in other languages (such as Halle, 1959 on Russian; Norlin, 1983 on Cairo Arabic; etc.). Clearly, fricatives are distinguishable on the basis of various acoustic properties like spectral shape, duration and formant transition. This section reports friction duration, preceding vowel duration $\left(\mathrm{V}_{1}\right)$, following vowel duration $\left(\mathrm{V}_{2}\right)$ and formant transition of Hindko fricatives. As given in section 2.1, Hindko has eight fricative segments articulated from five different places of articulation. These appear in voicing pairs except palatal $/ \delta /$ that has no voiced counterpart and glottal / $\mathrm{h} /$ that is without voiceless counterpart.

\subsection{Methodology}

The methodology used for this study is as given below: 


\subsubsection{Participants}

In total, ten Hindko speakers (five male and five female) participated in the study. The participants were born in Hazara Hindko dialectal area. All these are either in their twenties or thirties. Eight of them are graduate students while two are teachers at the university of AJ\&K. All the participants are multilingual. At home, they speak Hindko while elsewhere Urdu. However, classroom communication is in English to a great extent. None of them reported any history of language impairment. All of them had received no phonetic training and knowledge of this kind of experiment.

\subsubsection{Stimuli}

The stimuli contain Hindko words and non-words with a vowel-consonant-vowel (VCV) context, where $\mathrm{C}$ is the target fricative. To minimize variation from the vowel context, the same vowel / $\mathrm{i} /$ is used both in preceding $\left(\mathrm{V}_{1}\right)$ and following $\left(\mathrm{V}_{2}\right)$ the target C. For recording, a list of eight Hindko fricatives is prepared, which was written in Hindko script, as shown in the table below:

Table 4: List of target fricatives in iCi sequence.

\begin{tabular}{lll} 
Fricatives & Voiceless & Voi \\
\hline Labio-dental & ifi & ivi \\
Alveolar & isi & izi \\
Palatal & ifi & - \\
Velar & ixi & iri \\
Glottal & - & ifi
\end{tabular}

\subsubsection{Procedure}

Each participant repeated the 8 stimuli 3 times for a total of 24 stimuli per participant. Totally, 240 tokens ( 8 fricatives x 3 repetitions x 10 participants) were analyzed to determine acoustic cues. Before recording, a brief session of instruction regarding how and what to do was held. For familiarization, each participant rehearsed the target words. The list of target words was given and for each repetition the order was changed. The data were recorded using high fidelity microphone directly on PRAAT software package (Boersma, 2012). A statistical package for social sciences (SPSS) was used for statistical analysis where possible. 


\section{Results and discussion}

The following table shows the mean values of temporal properties in milliseconds (ms) and formant-1 $\left(\mathrm{F}_{1}\right)$ and formant-2 $\left(\mathrm{F}_{2}\right)$ in Hertz $(\mathrm{Hz})$.

Table 5: Mean durations of $V_{1}, V_{2}$, Friction (ms), $F_{1}-F_{2}: V_{1}$ and- $F_{1}-F_{2}: V_{2}$ of Hindko fricatives.

\begin{tabular}{lccccc}
\hline & & & & & \\
& Dur.-Vi & Dur. V & Dur. Friction & $\mathbf{F}_{\mathbf{1}}-\mathbf{F}_{\mathbf{2}}: \mathbf{V}_{\mathbf{1}}$ & $\mathbf{F}_{\mathbf{1}}-\mathbf{F}_{\mathbf{2}}: \mathbf{V}_{\mathbf{2}}$ \\
\hline ifi & 176 & 246 & 132 & $331-1668$ & $325-1692$ \\
ivi & 206 & 246 & 90 & $310-1732$ & $321-1692$ \\
isi & 183 & 244 & 137 & $317-1679$ & $319-1713$ \\
izi & 196 & 239 & 111 & $311-1685$ & $315-1706$ \\
ifi & 181 & 265 & 135 & $319-1801$ & $326-1794$ \\
ixi & 191 & 264 & 116 & $333-1721$ & $339-1702$ \\
iri & 210 & 250 & 98 & $328-1710$ & $330-1712$ \\
ifi & 197 & 220 & 89 & $307-1684$ & $325-1672$ \\
\hline
\end{tabular}

Table 5 illustrates the mean duration of $V_{1}, V_{2}$, friction (ms) and $F_{1}-F_{2}$ of $V_{1}$ as well as $\mathrm{V}_{2}$ for each of the fricatives in Hindko. For instance, the longest friction duration is $137 \mathrm{~ms}$ of alveolar voiceless fricative /s/ while the shortest is $89 \mathrm{~ms}$ of glottal voiced fricative $/ \mathrm{h} /$. The table also exhibits differences between durations of proceeding vowel, following vowel and frication among fricatives. To check the significance statistically a pairwise independent sample t-test was applied testing the difference between the duration of $\mathrm{V}_{1}$ and $\mathrm{V}_{2}$, friction duration between voiced and voiceless fricatives and $\mathrm{V}_{1}$ duration between voiced and voiceless fricatives. The results reject the null hypothesis that there is no difference. The difference between these pairs is highly significant as the P-value $(0.00,0.003,0.006)$ which is smaller than 0.05 the level of significance. Hence, duration of $\mathrm{V}_{1}$ and $\mathrm{V}_{2}$, friction duration between voiced and voiceless and duration of $\mathrm{V}_{1}$ between voiced and voiceless fricatives are clearly distinguishing acoustic cues for Hindko fricatives. All this is clearly visible in the spectrograms.

\subsection{Spectral cues of Hindko fricatives}

The following spectrograms given in Figures 1-5, with respect of the place of articulation of Hindko fricatives, exhibit the difference between them. In the spectrogram, the straight line is drawn to indicate duration of friction; the rectangle shows high frequency range indicating turbulent air and its concentration, the lower circle $F_{1}$ and upper circle $F_{2}$ at the onset position. 


\subsubsection{Labio-dental /f/ and /v/}

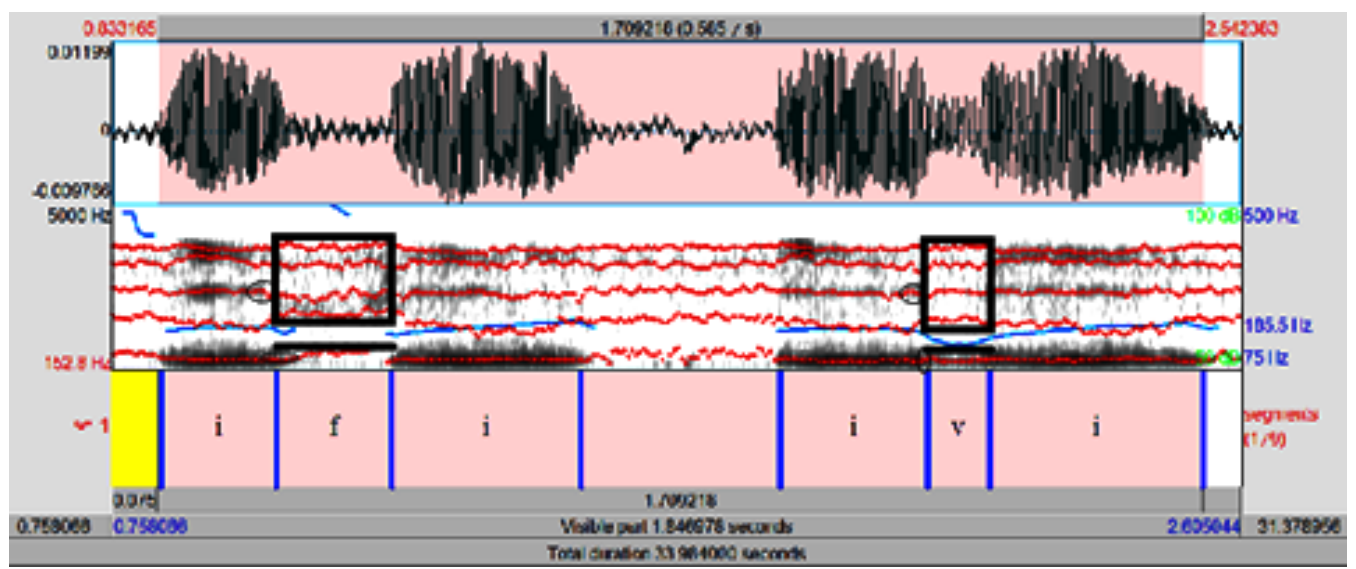

Figure 1: Spectrogram of labio-dental fricatives voiceless /f/ and voiced /v/.

This spectrogram given above indicates the durational difference between preceding and following vowels by segment marking, friction of /f/ and /v/ and the turbulent air in the high frequency range as in the rectangular area the noise is visible. In addition to, it shows that $F_{1}$ and $F_{2}$ falls at onset position of /f/ as well as /v/ while at offset position both $F_{1}$ and $F_{2}$ rise for voiceless /f/ and the same is true to its voiced counterpart /v/.

\subsubsection{Alveolar $/ \mathrm{s} /$ and /z/}

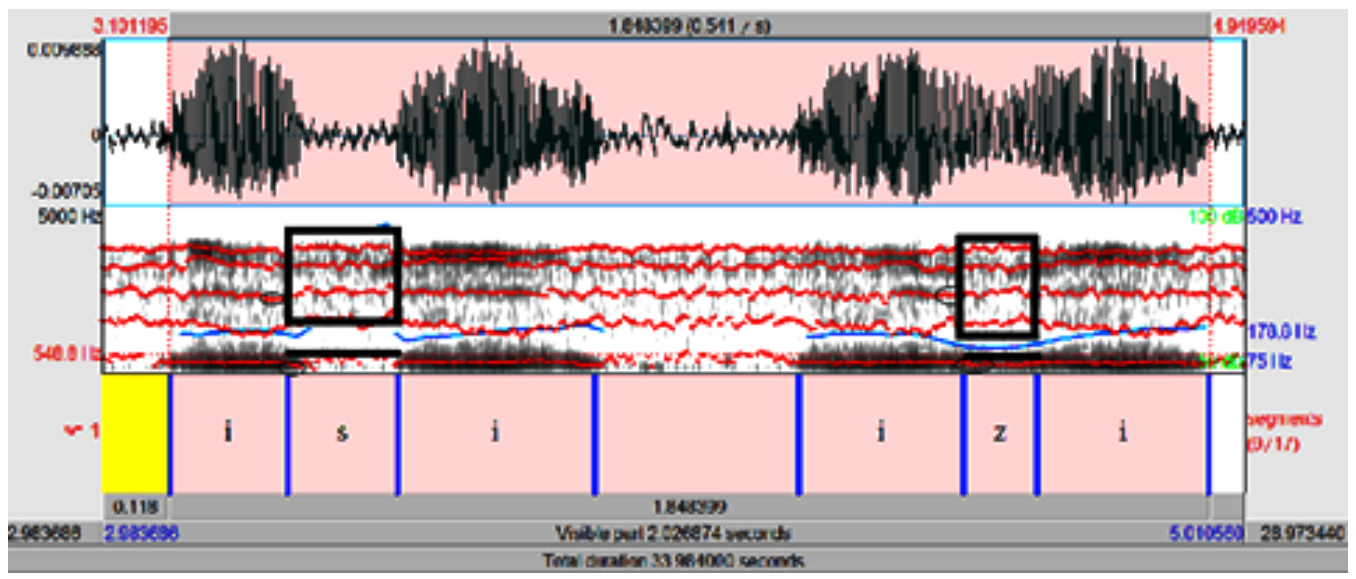

Figure 2: Spectrogram of Alveolar fricatives voiceless /s/ and voiced /z/.

Figure 2 reveals the durational differences of vowels, friction and turbulence in the high frequency range for $/ \mathrm{s} /$ and $/ \mathrm{z} /$. The absence of voice bar for $/ \mathrm{s} /$ demonstrates that it is voiceless while the presence of voice bar for /z/ that it is voiced. Further, it shows that 
$F_{1}$ drops at onset position while $F_{2}$ rises for $/ \mathrm{s} /$ and $/ z /$ as well. But at offset $F_{1}$ rises and $\mathrm{F}_{2}$ falls for both of these. The locus frequency of Hindko alveolar segments is 1600-1800 $\mathrm{Hz}$. So, it can be claimed that $\mathrm{F}_{2}$ transition for alveolar fricatives depends on neighboring vowel.

\subsubsection{Palatal / $\mathbf{~} /$}

Hindko has only one palatal fricative / $/$ / which is voiceless. It implies that it does not form pair.

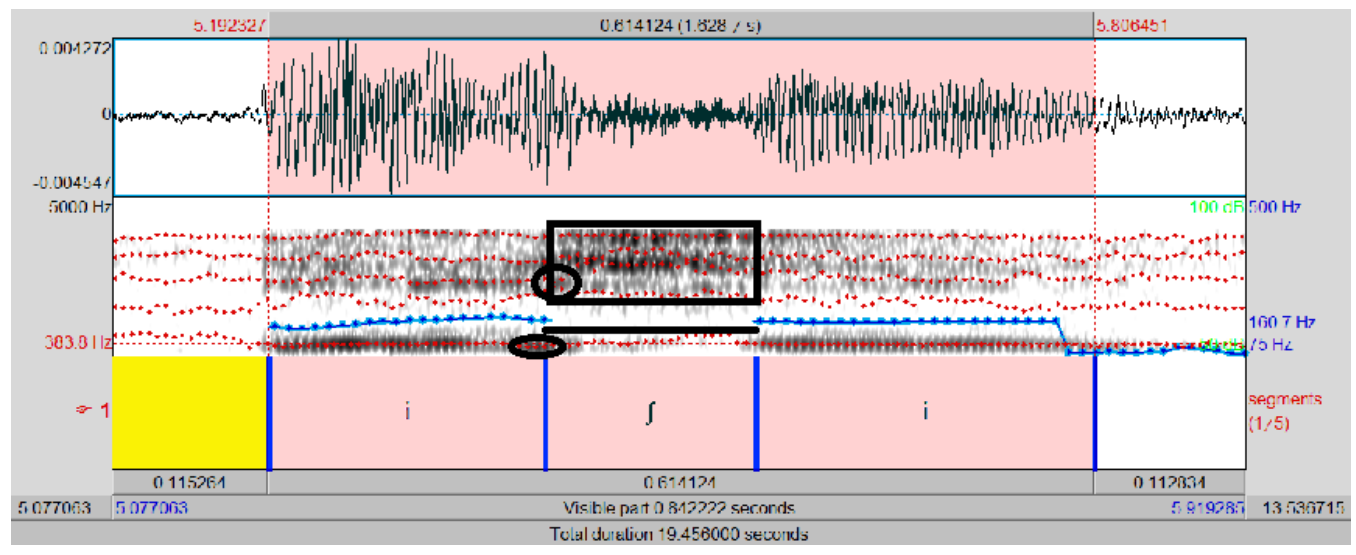

Figure 3: Spectrogram of Palatal voiceless fricative /J/.

The spectrogram given above in Figure 3 besides differentiating the duration difference of $V_{1}$ and $V_{2}$, reflects the friction duration of the voiceless fricative $/ g /$. The rectangle clearly shows the turbulent air is more than labio-dental and alveolar fricatives as shown in the spectrograms given in Figures 1 and 2 respectively. It is due to more area of the cavity in front of the constriction than labio-dental and alveolar segments supporting the claim by Pickett (1999) that the overall shape of the fricatives is known by the shape and size of the cavity in front of the constriction. In fact, the tube after constriction is long, thus, low frequencies come out and black bands also come down on spectrogram as can be seen in the spectrogram. Heins and Stevens (1961) identify a low frequency noise region for $/ \mathrm{J} /$. In Figure 3, dark bands are visible at about $2200 \mathrm{~Hz}$ and above. $F_{1}$ drops at onset and offset positions. The spectrogram also reflects that $F_{2}$ rise at onset while fall at offset. The locus frequency for $/ \int /$ is around $2000 \mathrm{~Hz}$.

\subsection{4 $\operatorname{Velar} / \mathbf{x} /$ and $/ \gamma /$}

The articulation of velar fricatives $/ \mathrm{x} /$ and $/ / \mathrm{r} /$ involves velum and back of the tongue, so, results in the long tube in front of the cavity. 


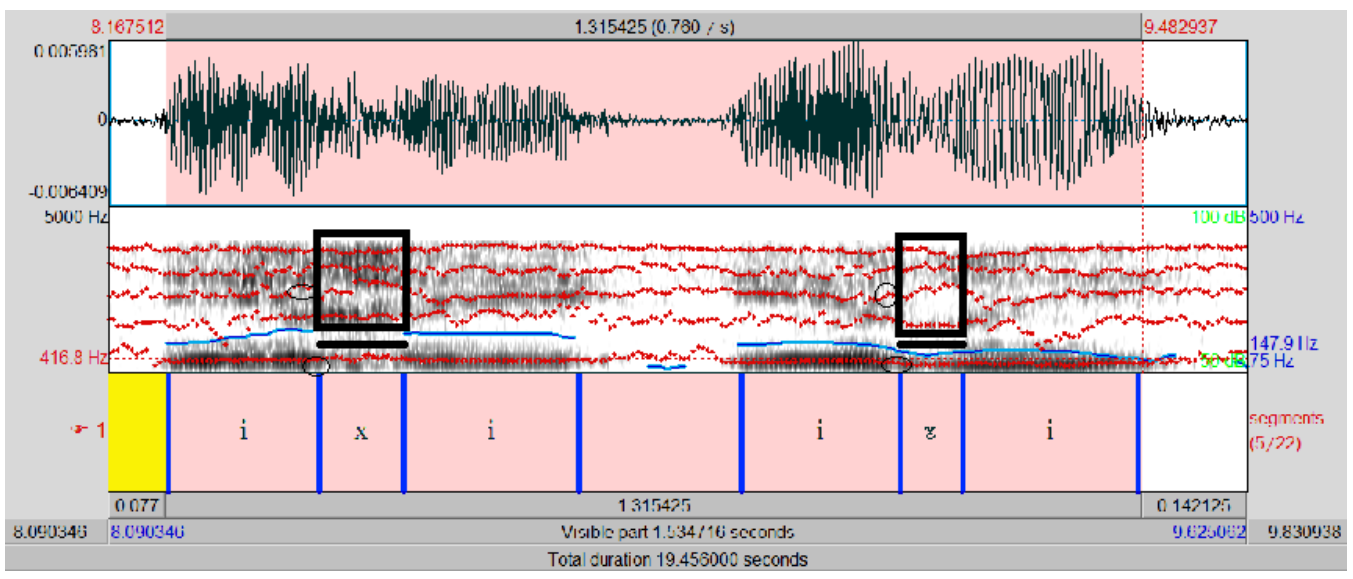

Figure 4: Spectrogram of velar fricatives voiceless $/ \mathrm{x} /$ and voiced $/ \gamma /$.

Figure 4 shows two dark bands of frequencies in the spectrogram. One is about 1100 $\mathrm{Hz}$ and the other is about $3300 \mathrm{~Hz}$. This is clearly seen for voiceless $/ \mathrm{x} /$ than voiced $/ \gamma /$. The spectrogram further reveals that $F_{1}$ drops at onset position while goes slightly upward. $\mathrm{F}_{2}$ demonstrates a rise at the onset but a sharp fall at offset as it has a locus frequency around $1200 \mathrm{~Hz}$.

\subsubsection{Glottal /h/}

The glottal fricative / $\mathrm{h} /$ is voiced in Hindko. There is no other fricative in Hindko produced from this place of articulation. As shown in Table v, it like other fricatives demonstrates a significant difference of $\mathrm{V}_{1}$ and $\mathrm{V}_{2}$ and friction duration in contrast with other voiceless fricatives. The formants are like vowels but fainter than vowels as shown in the spectrogram of voiced / $/ \mathrm{h} /$ below:

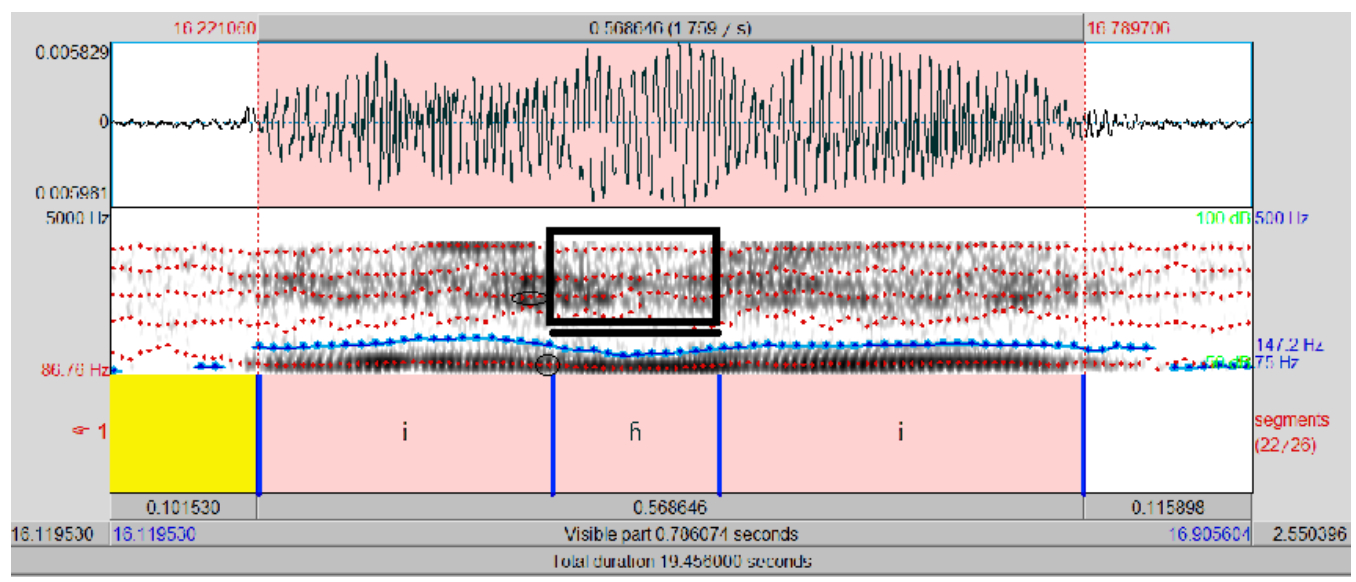

Figure 5: Spectrogram of glottal voiced fricative /h/. 
Turbulence noise is visible in all the fricatives. In regard with this Hindko fricatives can be further classified into strident and non-strident. Strident fricatives are produced with more energy than the non-strident fricatives. The spectrograms in Figures 1-5 show that the turbulence noise is strong for strident /s, $\mathrm{z}, \int /$ and weak for non-strident $/ \mathrm{f}, \mathrm{v}, \mathrm{x}$, $r, \mathrm{~h} /$.

\section{Findings}

This study on the acoustic cues of fricatives in Hindko finds that:

a. Duration of $\mathrm{V}_{1}$ is shorter than $\mathrm{V}_{2}$; duration of $\mathrm{V}_{1}$ of voiced fricative is more than voiceless fricative.

b. Friction duration is longer of voiceless fricatives than voiced ones. The longest fricative is voiceless alveolar /s/ and the shortest glottal voiced /h/.

c. The paired t-test results show the difference between the duration of $V_{1}$ and $V_{2}$; friction duration of voiceless and voiced and $\mathrm{V}_{1}$ duration difference of voiced and voiceless fricatives are highly significant.

d. Turbulence noise is present in all fricatives but it is strong for strident /s, z, J / and weak for non-strident /f, v, x, $\gamma, \mathrm{h} /$.

e. Voicing pairs (voiceless-voiced) are found at three places of articulation namely labio-dental /f, v/, alveolar/s, z/ and velar/x, r/ while palatal / / / is voiceless and glottal /h/ is voiced without their respective counterparts.

f. $F_{2}$ shows that formant transitions are in the direction of locus frequency of each fricative.

\section{Conclusion}

This work offers a phonemic and acoustic analysis of Hindko fricatives. The phonemic analysis demonstrates that Hindko has eight fricatives articulated from five different places of articulation. These are labio-dental /f, v/; alveolar /s, z/; palatal / $/$, velar /x, $\gamma /$ and glottal $/ \mathrm{h} /$. The voicing contrast is absent for palatal voiceless $/ \mathrm{f} /$ and glottal voiced /h/ while, the labio-dental, alveolar and velar fricatives form voicing pairs. These fricatives are studied acoustically.

The acoustic analysis reveals that Hindko fricatives are distinguishable on the basis of acoustic cues which are adjacent vowels duration, friction duration, formant transition and turbulence noise. The duration of $\mathrm{V}_{1}$ is shorter than $\mathrm{V}_{2}$; duration of $\mathrm{V}_{1}$ of voiced fricative is more than voiceless fricative. The friction trend is as it is longer for voiceless fricatives than voiced ones. The longest fricative is voiceless alveolar /s/ and the shortest 
glottal voiced /h/. The statistical analysis proves that these differences are significant. As far as turbulence noise is concerned, it is present in all fricatives as can be seen in the spectrogram given above. However, it is strong for strident $/ \mathrm{s}, \mathrm{z}, \mathrm{J} /$ and weak for nonstrident /f, v, x, $r, \mathrm{~h} /$. The glottal fricative /h/ has vowel like formants. Finally, the formant transition is in the direction of locus points of the respective place of articulation of fricative segments.

\section{References}

Boersma, P., \& David, W. (1999). Praat. Accessed from: http://.fon.hum.uva.nl.praat.

Davenport, M., \& Hannahs, S. J. (2005). Introducing phonetics \& phonology. UK: Hodder Education.

Haroon-ur-Rashid \& Sohail, A. (2011). A brief introduction of Hindko language.

Language in India, 11(11), 471-482.

Hughes, G. W., \& Halle, M. (1956). Spectral properties of fricative consonants. Journal of the Acoustical Society of America, 28, 303-310.

Halle, M. (1959). The sound pattern of Russian. The Hague: Mouton \& Co.

Heinz, J. M. \& Stevens, K. (1961). On the properties of voiceless fricative consonants.

The Journal of Acoustical Society of America, 33, 589-601.

Jongman, A., Wayland, R., \& Wong, S. (2000). Acoustic characteristics of English fricatives. The Journal of the Acoustical Society of America, 108, 1252-1263.

Kent, R. D. \& Charles, R. (1996). Acoustic analysis of speech. San Diego: Singular Publishing Group.

Ladefoged, P. (2001). A course in phonetics. USA: Harcourt College Publisher.

Lothers, M. \&Lothers, L. (2010). Pahari and Pothwari: A sociolinguistics survey Islamabad: Summer Institute of Linguistics.

Norlin, K. (1983). Acoustic analysis of fricatives in Cairo Arabic. Working Papers Lund University Department of Linguistics, 25, 113-137.

Pickett, J. M. (1999). The acoustics of speech communication fundamentals, speech perception theory, and technology. Boston: Allan and Bacon.

Tomiak, G.R. (1990). An acoustic and perceptual analysis of the spectral invariant with voiceless fricative obstruents (Unpublished doctoral dissertation). SUNY Buffalo. 